\title{
PENGGUNAAN MODEL PEMBELAJARAN PROBLEM BASE LEARNING (PBL) UNTUK MENINGKATKAN KEMAMPUAN BERPIKIR KRITIS PADA MATA PELAJARAN KIMIA SISWA KELAS XI MIPA 3 SMAN 1 BAMBANGLIPURO
}

\author{
Suyanta \\ SMA Negeri 1 Bambanglipuro \\ ysuyanta@yahoo.com
}

\begin{abstract}
Abstrak: Penelitian ini bertujuan untuk meningkatkan kemampuan berpikir kritis siswa SMAN 1 Bambanglipuro dengan menerapkan model pembelajaran Problem Based Learning (PBL) pada Mata Pelajaran Kimia.Penelitian ini merupakan penelitian tindakan kelas (PTK) yang dilaksanakan dalam 2 siklus. Tiap siklus terdiri atas perencanaan, pelaksanaan tindakan, observasi, dan refleksi. Subjek penelitian adalah siswa kelas XI_MIPA 3 SMAN 1 Bambanglipuro tahun pelajaran 2019/2020. Teknik yang digunakan dalam mengumpulkan data antara lain observasi, tes, dan dokumentasi. Analisis data yang digunakan mencakup penyajian data dan penarikan kesimpulan. Hasil penelitian menunjukkan bahwa Model Pembelajaran Problem Based Learning (PBL) pada Mata Pelajaran Kimia dapat meningkatkan kemampuan berpikir kritis siswa dengan hasil observasi kemampuan berpikir kritis pada siklus I sebesar $57,58 \%$ dan siklus II sebesar $78,79 \%$ dan hasil tes kemampuan berpikir kritis pada siklus I sebesar $45,45 \%$, siklus II sebesar $87,88 \%$. Kesimpulan penelitian ini adalah Model Pembelajaran Problem Based Learning (PBL) dapat meningkatkan kemampuan berpikir kritis siswa kelas XI MIPA 3 SMAN 1 Bambanglipuro.
\end{abstract}

Kata kunci: model pembelajaran problem based learning (PBL) dan kemampuan berfikir kritis

\section{USING THE PROBLEM BASE LEARNING (PBL) LEARNING MODEL TO IMPROVE CRITICAL THINKING ABILITY IN CHEMICAL LEARNING ABOUT TERMOCYMIA FOR STUDENTS IN CLASS XI MIPA 3 SMAN 1 BAMBANGLIPURO BANTUL}

\begin{abstract}
This research aims to improve students' critical thinking skills SMAN 1 Bambanglipuro by applying the Problem Based Learning (PBL) learning model to Chemistry Subjects. This research is a classroom action research (CAR) carried out in 2 cycles. Each cycle consists of planning, implementing actions, observing, and reflecting. The research subjects were students of class XI MIPA 3 of SMAN 1 Bambanglipuro in the academic year 2019/2020. Techniques used in collecting data include observation, tests, and documentation. Analysis of the data used includes the presentation of data and drawing conclusions. The results showed that the Problem Based Learning (PBL) Learning Model in Chemistry Subjects can improve students' critical thinking skills. The observations of critical thinking skills in cycle I were $57.58 \%$ and cycle II were $78.79 \%$ and test results critical thinking skills in the first cycle of $45.45 \%$, the second cycle of $87.88 \%$. The conclusion of this research is Problem Based Learning (PBL) Learning Model can improve critical thinking skills on Thermochemistry material for students of Class XI MIPA 3 SMAN 1 Bambanglipuro.
\end{abstract}

Keywords: problem based learning (PBL) learning model and critical thinking ability

\section{PENDAHULUAN}

Pembelajaran merupakan suatu proses mengatur lingkungan agar siswa dapat belajar, sehingga dapat memiliki kemampuan yang diharapkan. Salah satu kemampuan yang diharapkan dapat dimiliki siswa untuk menghadapi era global saat ini adalah kemampuan berpikir kritis, sehingga siswa tidak hanya menerima pendapat orang lain tetapi juga mampu mengungkapkan pendapatnya sendiri.

Menurut Preisseisen dalam Martinis Yamin (2013: 4), kemampuan berpikir kritis adalah kemampuan individu dalam menggunakan proses berpikirnya untuk menganalisis arguman dan memberikan interpretasi berdasarkan persepsi yang benar dan rasional, analisis asumsi dan biar dari argumen, dan interpretasi logis.

Berpikir kritis adalah kemampuan yang dipelajari yang membutuhkan instruksi dan praktik (Snyder, 2008: 90). Salah satu cara untuk meningkatkan kemampuan berpikir kritis siswa adalah melatihkan berpikir kritis selama proses pembelajaran yang mampu menciptakan semangat berpikir kritis, sehingga mendorong siswa mempertanyakan 
apa yang mereka dengar dan mengkaji pikiran mereka untuk memastikan tidak terjadi logika yang keliru.

Berdasarkan observasi yang dilakukan peneliti di Kelas XI-MIPA 3 SMAN 1 Bambanglipuro pada saat pembelajaran kimia ditemukan berbagai permasalahan, antara lain ketika mengerjakan tugas yang diberikan mecapai nilai diatas KKM, namun ketika Ulangan harian masih banyak yang belum mencapai KKM., model pembelajaran yang digunakan belum mampu mengembangkan kemampuan berpikir kritis, siswa karena siswa cenderung menghafal materi yang dipelajari. Beberapa siswa bahkan kurang tertarik saat pembelajaran berlangsung.

Berdasarkan uraian tersebut, perlu dilakukan penelitian agar siswa dapat mengembangkan kemampuan berpikir kritis, khususnya dalam pembelajaran kimia. Penelitian ini mencoba mengetahui secara empirik penerapan model Problem Based Learning (PBL) untuk meningkatkan kemampuan berpikir kritis siswa.

Salah satu variasi model pembelajaran yang terus dikembangkan untuk meningkatkan kemampuan berpikir kritis adalah model Problem Based Learning (PBL). Hal ini didukung oleh Semerci (2006: 1127) yang mengatakan bahwa baru-baru ini model PBL menarik perhatian dilihat sebagai faktor penting untuk mengembangkan perilaku berpikir kritis bagi siswa.

Kemampuan berpikir kritis sangat penting dimiliki oleh siswa karena dapat membantu menghadapi masalah yang semakin kompleks, baik terkait langsung dengan pembelajaran maupun terkait dengan kehidupan sehari-hari. Model PBL merupakan model yang mampu mengembangkan kemampuan berpikir kritis, pemecahan masalah, dan mengajak siswa untuk secara aktif membangun pengetahuan sendiri. Proses penemuan pengetahuan yang dilakukan secara aktif tersebut dapat berpengaruh positif pada daya ingat siswa terhadap pengetahuan yang telah diperoleh siswa.

\section{METODE PENELITIAN}

Penelitian ini tergolong penelitian tindakan kelas (PTK) dengan dua siklus. Masing-masing siklus terdiri atas tahap-tahap perencanaan, tindakan, observasi dan refleksi.

Subjek penelitian adalah siswa Kelas XIMIPA 3 semester ganjil SMAN 1
Bambanglipuro tahun pelajaran 2019/2020. Siswa laki-laki 9 orang, perempuan 24 orang dengan jumlah keseluruhan 33 orang. Pemilihan subjek dalam penelitian ini didasarkan pada pertimbangan bahwa subjek tersebut mempunyai permasalahanpermasalahan yang telah teridentifikasi pada saat observasi awal. Penggunaan model yang telah dirancang diharapkan tepat diterapkan pada siswa Kelas XI-MIPA.3 SMAN 1 Bambanglipuro. Objek penelitian ini adalah kemampuan berpikir kritis.

\section{Teknik Pengumpulan data}

Pengambilan data dalam penelitian ini dilakukan dengan 2 teknik, yaitu teknik observasi dan ujian. Teknik observasi digunakan untuk mengetahui proses pelaksanaan dan aktivitas siswa pada saat kerja kelompok dan presentasi. Teknik ujian digunakan untuk penilaian kemampuan berpikir kritis siswa.

\section{Instrumen Penelitian}

Instrumen dalam penelitian ini berupa instrumen perlakuan dan instrumen pengambilan data. Instrumen perlakuan meliputi Rencana Pelaksanaan Pembelajaran (RPP), lembar observasi siswa dan observasi guru, sedangkan instrumen pengambilan data meliputi tes dan tugas berupa soal kemampuan berpikir kritis.

Instrumen penelitian tersebut dijelaskan secara rinci antara lain (1) Rencana pelaksanaan pembelajaran (RPP) merupakan instrumen yang digunakan untuk memberikan perlakuan terhadap subyek penelitian (2) Lembar Observasi dibuat dua jenis yaitu Lembar Instrumen Obsevasi untuk siswa dan Lembar Instrumen Observasi untuk guru (3)Tes Kemampuan berpikir kritis siswa diukur dengan tes soal kemampuan berpikir kritis.Kemampuan berpikir kritis siswa dinilai berdasarkan jawaban soal yang dikerjakan oleh siswa. Soal untuk mengungkap kemampuan berpikir kritis siswa divalidasi secara logis. Kisi-kisi penilaian kemampuan berpikir kritis diadopsi berdasarkan teori Herr dalam Antuni Wiyarsi dan Efan Priyambodo (2011: 125) yaitu (1) Kemampuan menyajikan data secara mendetail (2) Kemampuan mengajukan pertanyaan yang banyak dan tepat (3) Kemampuan menggali informasi (4) Kemampuan menunjukkan perbedaan antar dua hal (5) Kemampuan menyatakan pendapat dengan menyertakan alasan atau perbandingan. 


\section{Teknik Analisis data}

Analsisis terhadap data-data yang didapatkan untuk penelitian tindakan kelas dimulai sejak awal sampai berakhirnya proses pengumpulan data. Persentase pada masingmasing siklus dihitung berdasarkan skor penilaian kemampuan berpikir kritis yang diperoleh siswa dengan rumus sebagai berikut:

$$
\text { Persentase }=\frac{\text { Skor diperoleh }}{\text { Skor maksimal }} \times 100 \%
$$

Siswa tuntas jika mempunyai persentase ketercapaian $\geq$ batas standar indikator.

\section{Prosedur Penelitian}

Penelitian ini termasuk penelitian tindakan kelas (PTK) dengan dua siklus. Tiap siklus dilaksanakan sesuai perubahan yang ingin dicapai. Prosedur yang digunakan dalam melaksanakan Penelitian Tindakan Kelas (PTK) ini mengikuti model yang dikembangkan oleh Kemmis dan Mc Taggart dalam Kasbolah (2001: 63-65) yakni berupa model spiral. Ada empat tahap dalam sistem spiral refleksi diri menurut Kemmis, yaitu rencana tindakan (planing), tindakan (acting), pengamatan (observing), dan refleksi (reflecting). Masing-masing siklus terdiri dari tahap-tahap empat tahap tersebut.

Jumlah total siklus yang dilaksanakan penelitian adalah 2 siklus. Jika siklus pertama yang telah dilaksanakan belum menunjukkan peningkatan yang diharapkan, maka siklus penelitian dilanjutkan hingga peneliti merasa berhasil.

\section{Siklus 1}

Kegiatan yang dilakukan pada siklus I ini proses pembelajaran mata pelajaran Kimia materi tentang Termokimia direncanakan dua kali pertemuan, untuk memperlancar dan mempermudah dalam pelaksanaan kegiatan pembelajaran dilakukan dengan menggunakan Lembar kerja Siswa agar materi pembelajaran mudah dipelajari dengan tahap demi tahap. Pada siklus 1 ini diakhiri dengan Refleksi.

Hasil analisis data yang dilaksanakan pada tahap ini, akan dipergunakan sebagai acuan untuk merencanakan siklus berikutnya. Jika hasil yang diharapkan belum tercapai maka dilakukan perbaikan yang dilaksanakan pada siklus kedua.

\section{Siklus 2}

Berdasarkan hasil refleksi tindakan siklus I, maka dilakukan revisi pada rancangan tindakan siklus II. Pelaksanaan tindakan pada siklus II ini merupakan kelanjutan pada siklus I yang dinyatakan belum mencapai standar yang diterapkan. Guru merubah rancangan tindakan yang dilakukan pada siklus II berdasarkan hasil observasi pada siklus I.

\section{Indikator Keberhasilan Penelitian}

Indikator keberhasilan tindakan terhadap peningkatan kemampuan berpikir kritis siswa Kelas XI-MIPA.3 SMAN 1 Bambanglipuro.

\begin{tabular}{cc}
\hline Indikator & Target \\
Kemampuan Berpikir Kritis & $75 \%$ \\
\hline
\end{tabular}

Perhitungan persentase ketuntasan adalah sebagai berikut:

$$
\text { Persentase }=\frac{\text { Banyak siswatuntas }}{\text { Banyak semua siswa }} \times 100 \%
$$

\section{HASIL DAN PEMBAHASAN}

Pada pembelajaran yang dipakai dalam Penelitian Tindakan Kelas ini dibentuk kelompok secara acak heterogen dengan mengurutkan menghitung siswa secara urut dari nomor 1 sampai nomor 8 hingga 4 kali bertututan hingga mendapatkan 4 kelompok nomor 1 hingga 8 , bagi siswa yang mengucapkan nomor yang sama menjadi kelompok sesuai nomor yang diucapkan. Dalam satu kelas terdiri dari 8 kelompok, dengan masing-masing kelompok terdiri 4 orang siswa, karena jumlah siswa ada 33 sehingga ada 1 kelompok yang terdiri dari 5 orang. Pembagian dilakukan secara heterogen dengan tujuan untuk menyetarakan kemampuan dasar siswa pada masing-masing kelompok. Kelompok dengan kemampuan heterogen akan menghidupkan proses diskusi kelompok, siswa yang memiliki kemampuan tinggi akan membantu siswa dengan kemampuan yang kurang. Sehingga, setiap kelompok akan bekerjasama untuk memahami pelajaran serta bertanggungjawab atas pemahaman setiap personil kelompok agar mendapatkan hasil yang terbaik.

Hasil penelitian menunjukkan bahwa Penilaian kemampuan berpikir kritis ditinjau dari aspek observasi berpikir kritis pada siklus 1 diperoleh hasil sebagai berikut. 
Tabel 4.1 Hasil observasi berpikir kritis Siklus 1

\begin{tabular}{ccccc}
\hline Indikator & 1 & 2 & 3 & 4 \\
\hline $\begin{array}{c}\text { Ketercapaian } \\
(\%)\end{array}$ & 90,15 & 63,64 & 56,06 & 65,15 \\
$\begin{array}{c}\text { Ketuntasan } \\
\text { siswa (\%) }\end{array}$ & \multicolumn{4}{c}{54,5} \\
\hline
\end{tabular}

Hasil ketuntasan pencapaian indikator berpikir kritis ditinjau hasil observasi. Pada hasil ketercapaian setiap indikator observasi memperoleh hasil indikator 1 (Interpretation/ Interpretasi) telah mencapai ketuntasan lebih dari target yang ditentukan yaitu sebesar $75 \%$, hal tersebut menunjukkan bahwa siswa telah mengerti dan dapat menyatakan materi yang telah dipelajari dalam bentuk pertanyaan yang sesuai dengan indikator yang telah diberikan. Sedangkan untuk aspek yang lain belum mencapai target ketuntasan atau kurang dari $75 \%$, dengan rincian indikator 2 (Interferencel kesimpulan) 63,6\%, indikator 3 (Evaluation/ evaluasi) $56,1 \%$, dan indikator 4 (Explanation/ penjelasan) $65,2 \%$.

Analisis hasil menunjukkan bahwa masih kurangnya kemampuan siswa dalam menyimpulkan, mengevaluasi, dan menjelaskan suatu pokok pembahasan. Ketuntasan penilaian kemampuan berpikir kritis siswa dari jumlah populasi siswa hanya mencapai $54,5 \%$ yang belum mencapai target minimal 75\%.

Pada siklus 1, indikator interprestasi telah mencapai target yang ditunjukkan dengan sebagian besar siswa mampu menyatakan materi yang dipelajari dalam bentuk pertanyaan yang sesuai dengan indikator yang ditentukan. Sedangkan indikator yang lain belum mencapai ketuntasan masing-masing dikarenakan siswa belum terbiasa untuk membuat pertanyaan yang berbobot dan sesuai dengan tujuan pembelajaran, belum terbiasa membuat soal tipe analisis (pencapaian hanya sampe tipe soal $\mathrm{C} 1$ dan $\mathrm{C} 2$ ), serta siswa menjawab pertanyaan tanpa adanya penjelasan. Langkah refleksi yang dilakukan untuk mengatasi hal tersebut yaitu dengan melakukan analisis wawancara tentang kesulitan yang dialami oleh siswa serta melakukan motivasi, arahan dan penjelasan cara bertanya dan menjawab yang baik.

Tabel 4.2. Hasil Tes Kemampuan berpikir Kritis Siklus 1

\begin{tabular}{ll}
\hline Nilai rata-rata & 59,70 \\
Ketuntasan $(\%)$ & 45,45 \\
\hline
\end{tabular}

Nilai rata-rata kelas yang dicapai pada tes kemampuan berpikir kritis siklus 1 sebesar 59,70 dengan persentase ketuntasan hanya sebesar $45,45 \%$. Hal tersebut sangat jauh dari target yang telah ditetapkan dalam KKM. Berdasarkan hasil observasi rubrik berpikir kritis yang telah dilakukan kepada siswaketidakberhasilan dalam peningkatan kemampuan berpikir kritis ini dikarenakan siswa belum terbiasa dengan tipe soal analisis berpikir kritis sehingga siswa bingung dalam memahami pertanyaan, belum bisa mengerjakan soal, serta kurang cakap dalam menyimpulkan, mengevaluasi, dan menjelaskan apa yang ingin diungkapkan.

Kurang terlatihnya siswa dalam mengerjakan tipe soal analisis ini juga menyebabkan siswa kebingungan dalam memahami soal analisis yang panjang, sehingga terjadi ketidaksinkronan antara soal dan jawaban yang disajikan oleh siswa. Tindakan yang selanjutnya dilaksanakan untuk mengatasi kelemahan pada siklus pertama ini yaitu dengan cara memberikan soal analisis sebagai latihan sehingga siswa terbiasa memahami dan menjawab tipe soal tersebut.

Sama seperti dengan penilaian yang dilaksanakan pada siklus 1, pada siklus 2 dilakukan penilaian kemampuan berpikir kritis terhadap jawaban, dengan tes. Berikut disajikan hasil kemampuan berpikir kritis dari hasil observasi.

Tabel 4.4. Hasil Observasi Siklus 2

\begin{tabular}{ccccc}
\hline Indikator & 1 & 2 & 3 & 4 \\
\hline $\begin{array}{c}\text { Ketercapaian } \\
(\%)\end{array}$ & 93,94 & 87,88 & 84,09 & 87,88 \\
$\begin{array}{c}\text { Ketuntasan } \\
\text { siswa (\%) }\end{array}$ & 78,79 & & & \\
\hline
\end{tabular}

Hasil observasi siswa menunjukkan bahwa kemampuan berpikir kritis siswa telah mencapai target yang telah ditentukan yaitu mencapai $\geq 75 \%$. Hal tersebut ditunjukkan pada persentase ketercapaian setiap indikator kemampuan berpikir kritis berturut-turut dari indikator 1 sampai 4 sebesar 93,94\%,87,88\%, $84,09 \%$, dan $87,88 \%$. Sedangkan nilai ketuntasan mencapai persentase 78,79\%. Dari data dapat disimpulkan bahwa kemampuan berpikir kritis siswa ditinjau dari hasil data observasi telah meningkat dibuktikan dengan tercapainya target awal siklus. Jika dibandingkan dengan siklus pertama hasil dapat dilihat pada grafik berikut. 


\section{CAPAIAN INDIKATOR}

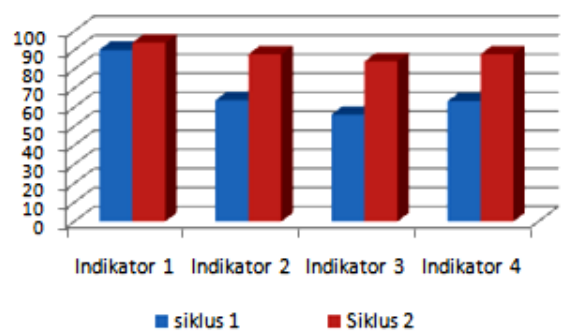

Gambar 4.1. Perbandingan hasil observasi capaian indikator siklus 1 dan siklus 2

Grafik 4.1 menunjukkan bahwa terjadi peningkatan kemampuan berpikir kritis siswa pada setiap indikator dari siklus 1 yang masih rendah dalam mencapai target kemudian meningkat pada siklus 2. Dengan ketercapaian siklus 2 melebihi target siklus yang ditentukan yaitu $\geq 75 \%$.

Penilaian kedua kemampuan berpikir kritis ditinjau dari tes kemampuan berpikir kritis. Berikut hasil tes kemampuan berpikir kritis pada siklus kedua.

Tabel 4.5. Hasil Tes Kemampuan Berpikir Kritis Siklus 2

\begin{tabular}{ll}
\hline Nilai rata-rata & 74,18 \\
\hline Ketuntasan (\%) & 87,88 \\
\hline
\end{tabular}

Pada siklus kedua hasil tes kemampuan berpikir kritis menunjukkan bahwa rata-rata kelas hasil tes sebesar 74,18. Dengan persentase jumlah siswa tuntas sebesar $87,88 \%$, hasil tersebut menyatakan bahwa ketuntasan tes kemampuan berpikir kritis telah mencapai target yang ditentukan. Berikut perbandingan Hasil Observasi Ketercapaian Berpikir Kritis dan ketuntasan tes kemampuan berpikir kritis pada siklus 1 dan 2 .

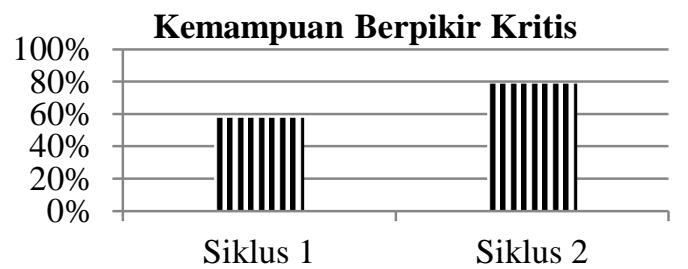

Gambar 4.2. Grafik perbandingan hasil observasi berpikir kritis pada siklus 1 dan 2.

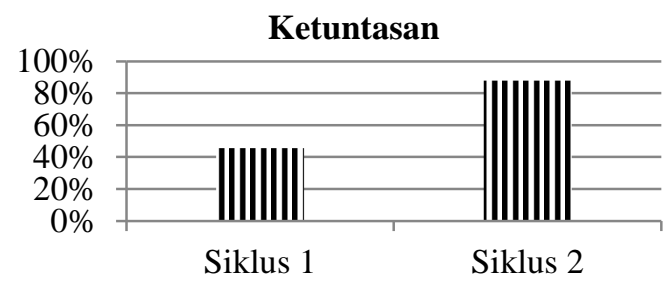

Gambar 4.3. Grafik perbandingan ketuntasan tes kempampuan berpikir kritis pada siklus 1 dan 2 .
Berdasarkan grafik 4.2 dapat dideskripsikan bahwa terjadi peningkatan presentase ketuntasan dari siklus 1 jika dibandingkan dengan siklus 2. Peningkatan keberhasilan tindakan pada kedua siklus sangat tajam dari $57,58 \%$ menjadi $78,79 \%$. Sedangkan grafik 4.3 dapat dideskripsikan bahwa terjadi peningkatan presentase ketuntasan dari siklus 1 jika dibandingkan dengan siklus 2. Peningkatan ketuntasan pada kedua siklus juga sangat segnifikan dari $45,45 \%$ menjadi $87,88 \%$. Dengan adanya peningkatan angka ketuntasan atau ketercapaian target tindakan menunjukkan bahwa angka ketidak tuntasan pada tes ini menurun sangat tajam juga. Dari kedua penilaian kemampuan berpikir kritis pada siklus 2 dapat disimpulkan bahwa kemampuan berpikir kritis siswa meningkat pada siklus ini dan telah mencapai target yang ditentukan.

\section{SIMPULAN}

Berdasarkan hasil analisa data dan pembahasan pada bab IV, maka penelitian yang telah dilaksnakan ini dapat disimpulkan bahwa Model pembelajaran Problem Based Learning (PBL) pada pembelajaran Kimia materi Termokimia dapat meningkatkan kemampuan berpikir kritis siswa bagi siswa kelas XI MIPA_3 di SMAN 1 Bambanglipuro Bantul tahun pelajaran 2019/2020. Kesimpulan yang ditarik oleh peneliti ini didasarkan aspek penilaian baik penilaian observasi maupun tes kemampuan.

Peningkatan kemampuan berpikir kritis siswa ditinjau dari aspek observasi dan tes kemampuan berpikir kritis sama-sama menunjukkan peningkatan yang signifikan mulai dari awal penelitian menuju siklus 1 hingga siklus 2. Peningkatan kemampuan berpikir kritis siswa ditinjau dari aspek observasi dengan ketercapaian ketuntasan $78,79 \%$. Sedangkan peningkatan kemampuan berpikir kritis siswa ditinjau dari aspek tes kemampuan adalah $87,88 \%$.

Peningkatan kemampuan berpikir kritis siswa akan meningkatkan kemampuan siswa dalam menginterprestasi, menyimpulkan, mengevaluasi, serta menjelaskan suatu materi atau topik yang diajarkan khusunya pada materi kimia.

\section{SARAN}

Berdasarkan hasil penelitian, maka dapat direkomendasikan beberapa hal antara laian sebagai berikut: 
1. Guru kimia, hendaknya terus berusaha untuk meningkatkan kemampuannya dalam mengembangkan materi, menyampaikan materi, serta dalam mengelola kelas, sehingga kualitas pembelajaran yang dilakukannya dapat terus meningkat seiring dengan peningkatan kemampuan yang dimilikinya. Selain itu, guru hendaknya mau membuka diri untuk menerima berbagai bentuk masukan, saran, dan kritikan agar dapat lebih memperbaiki kualitas mengajarnya, guru harus lebih kreatif dan inovatif dalam menerapkan metode dan model pembelajaran yang sesuai dengan tingkat kemampuan siswa supaya pembelajaran lebih bervariasi dan tidak monoton sehingga siswa tidak bosan.

2. Bagi siswa, agar aktif dan membiasakan berpikir kritis dalam mengikuti pelajaran supaya hasilnya lebih optimal.

3. Bagi sekolah, hendaknya berusaha menyediakan fasilitas yang dapat mendukung kelancaran kegiatan belajar mengajar kimia dan memberikan wadah penelitian tindakan kelas bagi guru.

\section{REKOMENDASI}

Model pembelajaran Problem Based Learning (PBL) merupakan salah satu model pembelajaran yang dapat meningkatkan kemampuan berpikir kritis dan siswa pada materi yang bersifat abstrak, analisis, serta berbasis pemahaman konsep dengan adanya kelemahan dan kelebihan pada:

1. Penelitian terbatas hanya pada materi yang berbasis teori sehingga perlu penyesuaian materi dalam penggunaan hasil penelitian.

2. Perlunya adaptasi siswa pada pertemuan pertama sehingga materi yang diajarkan jangan terlalu luas karena akan menyebabkan waktu tidak sesuai dengan rencana.

3. Perlu adanya penugasan mandiri apabila siswa belum terbiasa mengerjakan soal analisis.

\section{DAFTAR PUSTAKA}

Agus, Suprijono. (2009). Cooperative Learning Teori dan Aplikasi PAIKEM. Yogyakarta: Pustaka Pelajar.

Anderson, Lorin W \& David R Krathwohl. (2010). Kerangka Landasan untuk Pembelajaran, Pengajaran, dan Asesmen. Trj. Prihantoro. Yogyakarta: Pustaka Pelajar.
Budiningsih, Asri. 2005. Belajar dan Pembelajaran. Jakarta: Rineka Cipta.

Daryanto. (2009). Panduan Proses Pembelajaran Kreatif \& Inovatif. Jakarta: Publisher.

King, F.J, Goodson, L., \& Rohani, F. (2006). Higher Order Thinking Skills: Definition, Teaching Strategies, and Assesment. London: A publication of the Educational Services Program.

Magsino, R. M. (2014). Enhancing Higher Order Thinking Skills in a Marine Biology Class through ProblemBased Learning. Asia Pacific Journal of Multidisciplinary Research, 2 (5), 1-6.

Majid, Abdul. (2013). Strategi Pembelajaran. Bandung: Remaja Rosdakarya.

Pavlidis, P. (2011). Critical Thinking as Dialectics: A Hegelian-marxist Approach. Journal for Critical Education Policy Syudies. 8 (2): 74-102.

Rahayu, Sri. (2011). Peningkatan Kemampuan Berpikir Kritis siswa dengan model pembelajaran Problem Based Learning dengan tema 'pencemaran lingkungan dan cara mengatasinya' di kelas VII B SMP N 1 Prambanan Klaten tahun ajaran 2010/2011. Skripsi S1. Yogyakarta: FMIPA UNY.

Rusman. (2011). Model-model Pembelajaran Mengembangkan Profesionalisme Guru. Jakarta: Raja Grafindo Persada.

Setyaningsih, Ika. (2010). "Peningkatan Kemampuan Berpikir Kritis Peserta didik dengan Penerapan Problem Based Learning pada Materi Pokok Pencemaran Lingkungan Kelas X-D Semester II SMAN 4 Yogyakarta. Skripsi S1. Yogyakarta: FMIPA UNY

Sudarman. (2007). Problem Based Learning: Suatu Model Pembelajaran untuk Mengembangkan dan Meningkatkan Kemampuan Memecahkan Masalah. Jakarta: Dalam jurnal pendidikan inovatif.

Yamin, Martinis. (2013). Kiat Membelajarkan Siswa.Jakarta: Referensi (GP Press Group). 